\title{
Global mercury emissions to the atmosphere from anthropogenic and natural sources
}

\author{
N. Pirrone ${ }^{1}$, S. Cinnirella ${ }^{1}$, X. Feng ${ }^{2}$, R. B. Finkelman ${ }^{3}$, H. R. Friedli ${ }^{4}$, J. Leaner ${ }^{5}$, R. Mason ${ }^{6}$, A. B. Mukherjee ${ }^{7}$, \\ G. B. Stracher ${ }^{8}$, D. G. Streets ${ }^{9}$, and K. Telmer ${ }^{10}$ \\ ${ }^{1}$ CNR-Institute of Atmospheric Pollution Research - Division of Rende, Rende, Italy \\ ${ }^{2}$ State Key Laboratory of Environmental Geochemistry, Institute of Geochemistry, Chinese Academy of Sciences, \\ Guiyang, China \\ ${ }^{3}$ University of Texas, Dallas, USA \\ ${ }^{4}$ National Center for Atmospheric Research, Boulder, USA \\ ${ }^{5}$ CSIR, Stellenbosch, South Africa \\ ${ }^{6}$ Department of Marine Sciences, University of Connecticut, Hartford, USA \\ ${ }^{7}$ Department of Biological and Environmental Sciences, University of Helsinki, Helsinki, Finland \\ ${ }^{8}$ Division of Science and Mathematics, East Georgia College, Swainsboro, Georgia \\ ${ }^{9}$ Argonne National Laboratory, Argonne, USA \\ ${ }^{10}$ School of Earth and Ocean Sciences, University of Victoria, Victoria, Canada
}

Received: 4 November 2009 - Published in Atmos. Chem. Phys. Discuss.: 16 February 2010

Revised: 11 June 2010 - Accepted: 14 June 2010 - Published: 2 July 2010

\begin{abstract}
This paper provides an up-to-date assessment of global mercury emissions from anthropogenic and natural sources. On an annual basis, natural sources account for $5207 \mathrm{Mg}$ of mercury released to the global atmosphere, including the contribution from re-emission processes, which are emissions of previously deposited mercury originating from anthropogenic and natural sources, and primary emissions from natural reservoirs. Anthropogenic sources, which include a large number of industrial point sources, are estimated to account for $2320 \mathrm{Mg}$ of mercury emitted annually. The major contributions are from fossil-fuel fired power plants $\left(810 \mathrm{Mg} \mathrm{yr}^{-1}\right)$, artisanal small scale gold mining ( $400 \mathrm{Mg} \mathrm{yr}^{-1}$ ), non-ferrous metals manufacturing $\left(310 \mathrm{Mg} \mathrm{yr}^{-1}\right)$, cement production $\left(236 \mathrm{Mg} \mathrm{yr}^{-1}\right)$, waste disposal $\left(187 \mathrm{Mg} \mathrm{yr}^{-1}\right)$ and caustic soda production $\left(163 \mathrm{Mg} \mathrm{yr}^{-1}\right)$. Therefore, our current estimate of global mercury emissions suggests that the overall contribution from natural sources (primary emissions + re-emissions) and anthropogenic sources is nearly $7527 \mathrm{Mg}$ per year, the uncertainty associated with these estimates are related to the typology of emission sources and source regions.
\end{abstract}

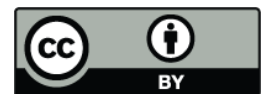

Correspondence to: N. Pirrone (pirrone@iia.cnr.it)

\section{Introduction}

Advances achieved during the last decade on mercury emissions from major man-made and natural sources have contributed to better constrain the assessment of the impact of atmospheric mercury deposition on terrestrial and aquatic environments (Pirrone et al., 2001a,c; Hedgecock et al., 2006; Dastoor and Davignon, 2009; Jaeglé et al., 2009; Jung et al., 2009; Seigneur et al., 2009; Travnikov and Ilyin, 2009; Bullock and Jaeglé, 2009).

Policy makers have also taken the advantage of improved information on emissions to assess the effectiveness of measures aimed to reduce the impact of this highly toxic contaminant on human health and ecosystems. For example, following the preparation of the EU Position Paper on Ambient Air Pollution by Mercury (Pirrone et al., 2001b) and the first assessment of mercury contamination on global scale (Global Mercury Assessment Report, GMA) (UNEP, 2002), the European Union adopted the European Mercury Strategy, which is aimed to phase out the use of mercury in goods and industrial applications and to reduce, to the extent possible, mercury emissions to the atmosphere from fossil-fuel power plants and industrial facilities. As follow up of the GMA report publication and the adoption of the European Mercury Strategy, a number of activities have been developed in order to support the achievement of the objectives set by the

Published by Copernicus Publications on behalf of the European Geosciences Union. 
UNEP Governing Council (decisions 23/9 in 2005, 24/3 in 2007 and 25/4 in 2009) aiming to elaborate possible strategies and mechanisms addressed to phase out the use of mercury in a wide range of products and reduce emissions from industrial plants.

Earlier studies of global mercury emissions were aimed primarily to assess the contributions from anthropogenic sources (Nriagu and Pacyna, 1988; Pirrone et al., 1996, 1998; Pacyna et al., 2003, 2006), particularly from coal, oil and wood combustion as well as from solid waste incineration and pyrometallurgical processes. Several studies have estimated emissions from volcanoes (Nriagu and Becker, 2003; Pyle and Mather, 2003; Ferrara et al., 2000), artisanal small scale gold mining (Lacerda, 1995; Veiga et al., 2006), reemission from oceans and surface waters (Pirrone et al., 2001a; Mason and Sheu, 2002; Hedgecock et al., 2006), top soil and vegetation (Gustin et al., 2000) and forest fires (Friedli et al., 2003; Cinnirella and Pirrone, 2006; Ebinghaus et al., 2007; Wiedinmyer and Friedli, 2007). More recently, assessments of mercury emissions to the global atmosphere have included the contribution of the most important anthropogenic and natural sources (AMAP/UNEP, 2008; Pacyna et al., 2010; Pirrone et al., 2009).

The evaluation of global emissions presented in this paper differs from previous published assessments because i) some new sources have been included in the estimate (e.g. vinyl chloride monomer production, coal-bed fires); ii) others have been updated (e.g. biomass burning, cement production), and iii) some regional estimates particularly with reference to coal combustion have been improved (i.e China, India).

\section{Mercury emissions from natural sources}

The estimate of mercury emissions from natural sources include the contribution from primary natural sources and reemission processes of historically deposited mercury over land and sea surfaces. The mercury emitted from volcanoes, geothermal sources and topsoil enriched in mercury pertains to primary natural sources, whereas the re-emission of previously deposited mercury on vegetation, land or water surfaces is primarily related to land use changes, biomass burning, meteorological conditions and exchange mechanisms of gaseous mercury at air-water/top soil/snow-ice pack interfaces (Pirrone et al., 2001b; Mason, 2009).

The contribution of volcanoes varies over time depending whether they are in a degassing or eruption phase. The $\mathrm{Hg} / \mathrm{SO}_{2}$ mass ratio is generally adopted to estimate mercury emissions, though this approach is very controversial because of the paucity of relevant data and their variability (Nriagu and Becker, 2003; Pyle and Mather, 2003). The $\mathrm{Hg} / \mathrm{SO}_{2}$ ratios of $10^{-4}$ for explosive volcanoes, $10^{-4}$ $10^{-6}$ for passive degassing volcanoes and $10^{-6}-10^{-7}$ for ash rich plumes have been used in several previous evaluations
(Nriagu and Becker, 2003; Pyle and Mather, 2003; Ferrara et al., 2000; Bagnato et al., 2009a). Mercury emissions from calderas may also represent an important natural source of mercury; the Phlegrean fields (Pozzuoli, Italy) show fluxes of mercury, as $\mathrm{Hg}-\mathrm{S}$ complexes, in the range of 0.9 to 19 $\mathrm{g} \mathrm{day}^{-1}$ (Ferrara et al., 2000; Bagnato et al., 2009b). On average, volcanoes and geothermal activities release about $90 \mathrm{Mg} \mathrm{yr}^{-1}$ of mercury to the atmosphere (Mason, 2009), accounting for nearly $2 \%$ of the total contribution from natural processes. Hereafter, GEb indicates the percentage calculated with reference to Global Emission, AEb the percentage calculated with reference to total Anthropogenic Emission and NAb the percentage calculated with reference to NAtural sources.

Several studies suggest that the evasion of elemental mercury from surface waters is primarily driven by (i) the concentration gradient of mercury between the top-water microlayer and air above the surface water, (ii) solar irradiation which is responsible for the photo-reduction of oxidized mercury in the top-water microlayer, and (iii) the temperature of the top-water microlayer and air above the surface water (air-water interface) (Pirrone et al., 2003, 2005; Hedgecock et al., 2006). The evasion of mercury from lake surfaces is generally higher than that observed over the sea. In general, internal waters show a maximum net evasion of $2.39 \mathrm{ng} \mathrm{m}^{-2} \mathrm{~h}^{-1}$. Over the open sea, mercury emission rates were found to be in the range of $1.16-2.50 \mathrm{ng} \mathrm{m}^{-2} \mathrm{~h}^{-1}$, though dissolved mercury concentrations in the top-water microlayer $\left(6.0 \mathrm{ng} \mathrm{L}^{-1}\right)$ were very similar to those observed in unpolluted coastal areas. On average, coastal waters and the Mediterranean Sea have the highest evasional flux, 1.83 and $1.96 \mathrm{ng} \mathrm{m}^{-2} \mathrm{~h}^{-1}$, respectively. (Pirrone et al., 2003; Hedgecock et al., 2006). Mason (2009) reports recent estimates of total mercury evasion from ocean basins and lakes, which account for $2778 \mathrm{Mg} \mathrm{yr}^{-1}$ (37\% GEb) of net gaseous mercury evasion to the atmosphere.

Mercury emissions from top soils and vegetation are significantly influenced by meteorological conditions, historical atmospheric deposition and the type of vegetation and top soil. Mercury fluxes from unaltered or background sites in North America have been found to be in the range of -3.7 to $9.3 \mathrm{ng} \mathrm{m}^{-1} \mathrm{hr}^{-1}$, and are similar to those observed in other background areas. In altered geologic sites the mean mercury flux was $15.5 \pm 24.2 \mathrm{ng} \mathrm{m}^{-1} \mathrm{hr}^{-1}$ on average, and highest values up to $3334 \mathrm{ng} \mathrm{m}^{-1} \mathrm{hr}^{-1}$ were found where calcine waste had been disposed off (Nacht and Gustin, 2004). Mercury emissions from vegetation depend upon several factors, including mercury uptake from the atmosphere, atmospheric deposition to foliage and mercury uptake from roots (Rea et al., 2002); however, the proximity of vegetation to natural or anthropogenic sources (hot spots or contaminated sites) may increase its mercury content (Lodenius, 1998; Lodenius et al., 2003). Recent studies show that most of the mercury found in foliage tissue originates from the atmosphere (Ericksen et al., 2003; Ericksen and Gustin, 2004). Summing 
Table 1. Global mercury emissions by natural sources estimated for 2008.

\begin{tabular}{lll}
\hline Source & $\begin{array}{l}\text { Mercury } \\
\left(\mathrm{Mg} \mathrm{yr}^{-1}\right)\end{array}$ & $\begin{array}{l}\text { Contribution } \\
(\%)\end{array}$ \\
\hline Oceans & 2682 & 52 \\
Lakes & 96 & 2 \\
Forests & 342 & 7 \\
$\begin{array}{l}\text { Tundra/Grassland/Savannah/ } \\
\text { Prairie/Chaparral }\end{array}$ & 448 & 9 \\
$\begin{array}{l}\text { Desert/Metalliferous/Non-vegetated } \\
\text { Zones }\end{array}$ & 546 & 10 \\
$\begin{array}{l}\text { Agricultural areas } \\
\text { Evasion after mercury depletion } \\
\text { events }\end{array}$ & 128 & 2 \\
$\begin{array}{l}\text { Biomass burning } \\
\text { Volcanoes and geothermal areas }\end{array}$ & 675 & 4 \\
TOTAL & 90 & 13 \\
\hline
\end{tabular}

up all the net evasional fluxes from all regions and media (Forests, Tundra/Grassland/Savannah/Prairie/Chaparral, Desert/Metalliferrous/Non-vegetated Zones and Agricultural areas) the total net global mercury evasion is $1464 \mathrm{Mg} \mathrm{yr}^{-1}$ (Mason, 2009).

Mercury emissions from biomass burning have only recently been considered in regional and global estimates (Friedli et al., 2003; Cinnirella and Pirrone, 2006; Wiedinmyer and Friedli, 2007; Cinnirella et al., 2008; Friedli et al., 2009a,b). The most recent estimate suggests that on a global scale nearly $675 \mathrm{Mg}$ of mercury is released to the atmosphere from biomass burning every year (annual average for the period 1997-2006), which accounts for about $13 \%$ of the total contribution from natural sources (Friedli et al., 2009a). The highest contributing regions (Fig. 1) are equatorial Asia (28\%), boreal Asia (15\%) and Southern Hemisphere South America (14\%). The part of Africa located in the Northern Hemisphere represents $12 \%$ of the global contribution, followed by Southern Hemisphere Africa (9\%), southeast Asia (8\%), central America (4\%) and Australia (3\%). The contribution from temperate North America (1\%), boreal North America (3\%), central Asia, Northern Hemisphere South America, Europe and Middle East combined (2\%) is minor.

The current estimate of mercury emissions from natural processes (primary mercury emissions + re-emissions), including mercury depletion events, is estimated to be $5207 \mathrm{Mg} \mathrm{yr}^{-1}$ (Table 1), which represent nearly $70 \%$ of the global mercury emission budget. Oceans are the most important sources $(36 \% \mathrm{GEb})$ followed by biomass burning $(9 \%$ $\mathrm{GEb})$, deserts, metalliferous and non-vegetated zones (7\% $\mathrm{GEb})$, tundra and grassland $(6 \% \mathrm{GEb})$, forests $(5 \% \mathrm{GEb})$ and evasion after mercury depletion events $(3 \% \mathrm{GEb})$.

Overall, the relative contribution of terrestrial surfaces is $2429 \mathrm{Mg} \mathrm{yr}^{-1}$ (47\% NAb) and that from surface waters is $2778 \mathrm{Mg} \mathrm{yr}^{-1}$ (53\% NAb). On an area basis, emissions from

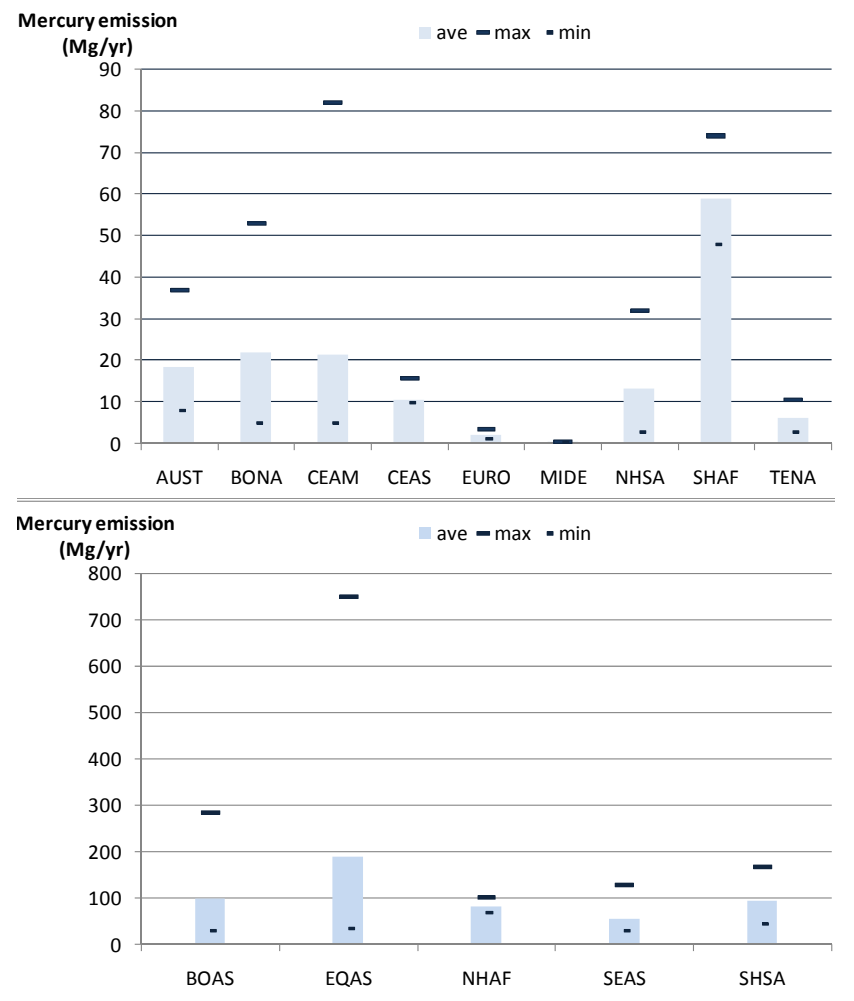

Fig. 1. Mercury emissions from biomass burning in Australia (AUST), boreal Asia (BOAS), boreal North America (BONA), central America (CEAM), central Asia (CEAS), Equatorial Asia (EQAS), Europe (EURO), Middle East (MIDE), Northern Hemisphere Africa (NHAF), Northern Hemisphere South America (NHSA), southeast Asia (SEAS), Southern Hemisphere Africa (SHAF), Southern Hemisphere South America (SHSA), temperate North America (TENA) (original data from (Friedli et al., 2009a)).

land (surface $1.46 \times 10^{8} \mathrm{~km}^{2}$ ) are higher than those from the ocean (surface $3.49 \times 10^{8} \mathrm{~km}^{2}$ ). Biomass burning represents $28 \%$ of emissions from land, whereas desert and nonvegetated zones represent $23 \%$ of the total, followed by tundra and grassland with $18 \%$ and forest with $14 \%$ of the total emission from land. Primary natural sources account for about $4 \%$ of current terrestrial outputs.

\section{Mercury emissions from anthropogenic sources}

Mercury is released to the atmosphere from a large number of man-made sources, which include fossil-fuel fired power plants, ferrous and non-ferrous metals manufacturing facilities, caustic soda production plants, ore processing facilities, incinerators for urban, medical and industrial wastes, cement plants and chemicals production facilities.

Three main parameters are used when estimating mercury emission from different industrial processes: the bulk material amount, the mercury content of the material and the 
Table 2. Emission factors adopted to estimate the emissions (from (Pacyna et al., 2006; Streets et al., 2009b)).

\begin{tabular}{lll}
\hline Source category & Unit & $\begin{array}{l}\text { Emission } \\
\text { factor }\end{array}$ \\
\hline $\begin{array}{l}\text { Coal combustion power plants } \\
\text { Coal combustion in residential and } \\
\text { commercial boilers }\end{array}$ & $\mathrm{g} \mathrm{Mg}^{-1}$ & $0.04-0.3$ \\
Oil combustion & & $0.1-0.5$ \\
Biofuel combustion & $\mathrm{g} \mathrm{Mg}^{-1}$ & 0.058 \\
Cu smelting & $\mathrm{g} \mathrm{Mg}^{-1}$ & 0.02 \\
Pb smelting & $\mathrm{g} \mathrm{Mg}^{-1}$ & $5.0-6.0$ \\
Zu smelting & $\mathrm{g} \mathrm{Mg}^{-1}$ & 3.0 \\
Cement production & $\mathrm{g} \mathrm{Mg}^{-1}$ & $7.5-8.0$ \\
Pig iron and steel production & $\mathrm{g} \mathrm{Mg}^{-1}$ & $0.065-0.1$ \\
Municipal wastes incineration & $\mathrm{g} \mathrm{Mg}^{-1}$ & 0.04 \\
Sewage sludge wastes & $\mathrm{g} \mathrm{Mg}^{-1}$ & 1.0 \\
Mercury production (Primary) & $\mathrm{g} \mathrm{Mg}^{-1}$ & 5.0 \\
Gold production (Large scale) & $\mathrm{kg} \mathrm{gg}^{-1}$ & 0.2 \\
\hline
\end{tabular}

technology adopted to reduce emissions (abatement technology). The combination of mercury concentration in the material and the type and efficiency of abatement technology lead to the emission factor. Most used emission factors derived from literature are reported in Table 2. These emission factors have been used in our estimates for the assessment of mercury emission from each source category.

The installation of BATs in industrial plants plays a fundamental role in the emission control as most technologies can reduce mercury emissions up to 95\% (USEPA, 1997, 2002a,b; Wang et al., 2010). Removal efficiency depends from adopted technology and production process (Table 3). Fossil fuels-fired power plants are the largest point sources of mercury released to the atmosphere, though other emission sources (e.g. artisanal gold mining) provide an important contribution to the global atmospheric budget (Pirrone et al., 2009).

World coal consumption in 2006 was $6118 \mathrm{Tg}$, representing the primary fuel used in electrical power generation facilities (42\%) and accounts for about the $27 \%$ of world's energy consumption (EIA, 2009). Although it is very difficult to generalize the mercury concentration in coal, the literature indicates that the mercury content in coal varies between 0.01 and $1.5 \mathrm{~g}$ per Mg (Toole-O'Neil et al., 1999; Mukherjee et al., 2008; Pirrone et al., 2009) (Table 4). The concentration of mercury is somewhat lower in lignite coals than in bituminous and sub-bituminous coals. However, the lower heating values of lignite coals relative to bituminous and subbituminous coals suggest that the amount of lignite burned per MW of energy produced is higher compared to other coal types (Tewalt and Finkelman, 2001). Moreover, concentrations of mercury within the same mining field may vary by one order of magnitude or more (Mukherjee et al., 2009).
Table 3. Median mercury removal efficiency (\%) for some technologies and different categories (from (USEPA, 1997, 2002a,b; Wang et al., 2010))

\begin{tabular}{|c|c|c|c|c|c|}
\hline Technology & Coal & Cement & Waste & Soda & Battery \\
\hline ESP & 32 & 25 & & & \\
\hline $\mathrm{FF}$ & 42 & 50 & & & 75 \\
\hline FGD & 34 (18-97) & - & & & \\
\hline $\mathrm{SDA}+\mathrm{ESP}$ & $67(23-83)$ & - & & & \\
\hline $\mathrm{SDA}+\mathrm{FF}$ & $30(6-97)$ & - & & & \\
\hline $\mathrm{AC}$ & & & $50-95$ & & \\
\hline GSC & & & & 90 & \\
\hline ME & & & & 90 & \\
\hline AAC & & & & 90 & \\
\hline
\end{tabular}

ESP=Electrostatic precipitators; FF=Fabric Filter; FGD=Flue Gas Desulfurization; SDA=Spry Drier Absorber; $\mathrm{AC}=$ Activated Carbon; GSC=Gas Stream Cooling; $\mathrm{ME}=$ Mist Eliminators; AAC $=$ Adsorption on Activated Carbon.

ESP or FF installed before.

or sodium sulfide.

Table 4. Mercury concentration $\left.\left(\mu \mathrm{g} \mathrm{g}^{-1}\right)\right)$ in coals from different geographic regions $\left(\mathrm{Mg} \mathrm{yr}^{-1}\right)$.

\begin{tabular}{llll}
\hline Country/region & Hg in coal & $\begin{array}{l}\mathrm{Hg} \text { in coal } \\
\text { fly ash }\end{array}$ & Reference \\
\hline Australia & $0.01-1.0$ & 0.34 & $(1)$ \\
China & $0.19-1.95$ & - & $(1),(2)$ \\
Guizhou Province & 0.52 & - & $(1)$ \\
Europe & $0.01-1.5$ & 0.23 & $(1)$ \\
India & $0.11-0.80$ & $0.007-0.28$ & $(1)$ \\
Japan & 0.045 & - & $(1)$ \\
Korea & $0.012-0.048$ & - & $(1)$ \\
Russia & $0.02-0.9$ & & $(1)$ \\
South Africa & $0.01-1.0$ & $0.56-0.64$ & $(1)$ \\
Argentina & $0.021-0.96$ & & $(3)$ \\
Brazil & $0.041-0.778$ & & $(3)$ \\
Colombia & $0.020-0.17$ & & $(3)$ \\
Peru & $0.041-0.63$ & & $(3)$ \\
Venezuela & $0.030-0.280$ & 0.268 & $(3)$ \\
USA & 0.17 (mean) & & $(4)$ \\
World & $0.02-1.0$ & 0.62 & \\
\hline
\end{tabular}

References: (1) (Mukherjee et al., 2008); (2) (Wang et al., 2000); (3) (Karlsen et al., 2006); (4) (Toole-O’Neil et al., 1999).

In developing countries and in countries with economies in transition (i.e., India) wood waste is primarily used to produce heat in the industrial sector, while wood is used in fireplaces and wood stoves in the residential sector with no emission control technology. Insufficient data are available, however, to estimate the typical mercury content of wood and wood wastes (Mukherjee et al., 2009).

Mercury emission from oil burning, as part of the fossil fuels category, represents a minor contribution compared to 
Table 5. Global emissions of total mercury from major anthropogenic sources $\left(\mathrm{Mg} \mathrm{yr}^{-1}\right)$.

\begin{tabular}{|c|c|c|c|c|c|c|c|c|c|c|c|c|}
\hline & $\mathrm{SC}^{\mathrm{a}}$ & NFMP & PISP & $\mathrm{CP}$ & CSP & MP & GP & WD & $\mathrm{O}$ & $\mathrm{T}$ & $\begin{array}{l}\text { Reference } \\
\text { year }\end{array}$ & Reference $^{b}$ \\
\hline S. Africa & 32.6 & 0.3 & 1.3 & 3.8 & 0.0 & 0.0 & 0.3 & 0.6 & 1.3 & 40.2 & 2004 & (1) \\
\hline China & 268.0 & 203.3 & 8.9 & 35.0 & 0.0 & 27.5 & 44.7 & 14.1 & 7.6 & 609.1 & 2003 & (2) \\
\hline India & 124.6 & 15.5 & 4.6 & 4.7 & 6.2 & 0.0 & 0.5 & 77.4 & 7.5 & 240.9 & 2004 & (3) \\
\hline Australia & 2.2 & 11.6 & 0.8 & 0.9 & 0.0 & 0.0 & 0.3 & 0.2 & 0.6 & 16.6 & 2005 & (4) \\
\hline Europe & 76.6 & 18.7 & 0.0 & 18.8 & 6.3 & 0.0 & 0.0 & 10.1 & 14.7 & 145.2 & 2005 & (5) \\
\hline Russia & 46.0 & 5.2 & 2.6 & 3.9 & 2.8 & 0.0 & 4.3 & 3.5 & 1.5 & 69.8 & 2005 & (5) \\
\hline N. America & 65.2 & 34.7 & 12.8 & 15.1 & 10.3 & 0.0 & 0.0 & 13.0 & 1.7 & 152.8 & 2005 & (6) \\
\hline S. America & 8.0 & 13.6 & 1.8 & 6.4 & 2.2 & 0.0 & 16.2 & 0.0 & 1.5 & 49.7 & 2005 & (5) \\
\hline Total & 623.2 & 302.9 & 32.8 & 88.6 & 27.8 & 27.5 & 66.3 & 118.9 & 36.4 & 1324.3 & & \\
\hline Rest of the world & 186.8 & 7.1 & 10.4 & 147.1 & 135.1 & 22.5 & 333.7 & 68.5 & 28.2 & 939.4 & 2006 & (7) \\
\hline Total & 810.0 & 310.0 & 43.2 & 235.7 & 162.9 & 50.0 & 400.4 & 187.4 & 64.6 & $2319.7^{\mathrm{c}}$ & & \\
\hline
\end{tabular}

${ }^{a}$ SC, Stationary combustion; NFMP, Non-ferrous metal production; PISP, Pig iron and steel production; CP, Cement production; CSP, Caustic soda production; MP, Mercury production; GP, Gold production; WD, Waste disposal; CB, Coal-bed fires; VCM, Vinyl chloride monomer production; O, Other; T, Total.

b References: (1) (Leaner et al., 2009); (2) (Feng et al., 2009; Streets et al., 2009a); (3) (Mukherjee et al., 2009); (4) (Nelson, 2007); (5) (AMAP/UNEP, 2008); (6) (USEPA, 2005; Canada, 2008; CEC, 2001); (7) (Feng et al., 2009; Streets et al., 2009b).

c This sum considers also CB and VCM estimates, which account for $32.0 \mathrm{Mg} \mathrm{yr}^{-1}$ and $24 \mathrm{Mg} \mathrm{yr}^{-1}$ respectively. Totals for countries do not include these values.

that emitted from coal combustion. The list of the top five consumers of oil for power generation facilities include the USA, Japan, Russia, China and Germany. Relatively large volumes of distillate and residual oils are burned each year in the world. These fuels are used by electric utilities, commercial and industrial boilers (which, depending on their size, may be fired by either residual or distillate oils or a combination thereof) and residential boilers as well. Fuel oils contain mercury with concentrations that vary with crude oil type (Wilhelm, 2001). These values range from 0.007 to $30 \mathrm{~g} \mathrm{Mg}^{-1}$, with a typical value being $3.5 \mathrm{~g} \mathrm{Mg}^{-1}$ (Wilhelm, 2001; Mukherjee et al., 2009). It is expected that mercury concentrations in residual oils are higher than those found in distillate oils, the latter being produced at an earlier stage in oil refineries. Heavier refinery fractions, including residual oils, contain higher quantities of mercury.

Natural gas may contain small amounts of mercury but the element is normally removed from the raw gas during the recovery of liquid constituents as well as during the removal of hydrogen sulfide. Therefore, it is assumed that mercury emissions from natural gas combustion are not significant when compared to those from other sources (Pirrone et al., 1996, 2001b).

Mercury emissions from stationary combustion facilities are certainly affected by the type and efficiency of control equipment, such as electrostatic precipitators (ESPs) and fabric filters (FFs) that are now commonly used as abatement measures in major electric power plants and central heating plants worldwide. Also flue gas desulfurization (FGD) units are used to control emissions but they are not common, especially in countries with economies in transition.
The combustion of fossil fuels (primarily coal) in stationary combustion (SC) facilities represents the most important anthropogenic source of mercury released to the global atmosphere annually (35\% $\mathrm{AEb})$ accounting for about $810 \mathrm{Mg} \mathrm{yr}^{-1}$, with an important contribution from Asian countries (nearly $50 \%$ of the total) (Table 5). Global mercury emissions were also estimated on the basis of world coal consumption in fossil fuel-fired power plants $(3400 \mathrm{Tg}$ ) and mercury emission factors in the range of $0.1-0.3 \mathrm{~g}^{-1}$ (EEA, 2009); the global mercury emission of $747 \mathrm{Mg}^{-1}$ $\left(\min 374 \mathrm{Mg}^{-1}\right.$ and $\max 1121 \mathrm{Mg}^{-1}$ ) represents the majority (>90\%) of mercury released to the atmosphere from SC facilities. On average, the uncertainty associated with these estimates is $\pm 25 \%$, as suggested by Swain et al. (2007) and Pacyna et al. (2009).

Mercury appears as an impurity of copper, zinc, lead and nickel ores as well as in gold ores (emissions from gold mining are discussed in the following section). Smelting processes to obtain these metals are known to be large sources of mercury released to the atmosphere, especially in developing countries (UNEP, 2002; Telmer and Veiga, 2009). Increasing trends in non-ferrous metal production by different processes, especially in new emerging countries, are leading to an increase of mercury releases to the atmosphere. Combustion temperatures in boilers, furnaces and roasters are key parameters affecting the amount of mercury released into the atmosphere though the chemical form and particle size distribution, and emission control technologies play an important role (Pirrone et al., 1996, 2001b). It is very difficult to discuss the average content of mercury in the copper, zinc, lead, nickel and gold ores as very little information 
is available in the literature. On the basis of a US Geological Survey, best estimates of mercury emitted from nonferrous ore processing are about $310 \mathrm{Mg} \mathrm{yr}^{-1}$ (USGS, 2004) with consistent differences with previous estimates (Pacyna et al., 2006; Hylander and Herbert, 2008; Pacyna et al., 2010) due to a substantial contribution from China which is about $203 \mathrm{Mg} \mathrm{yr}^{-1}$ (Streets et al., 2005, 2009a) (Table 2). The global annual contribution of about $276 \mathrm{Mg} \mathrm{yr}^{-1}$ reported by Hylander and Herbert (2008) includes a small release of mercury $\left(83 \mathrm{Mg} \mathrm{yr}^{-1}\right)$ from smelting processes in China.

Emissions of mercury from primary and secondary pig iron and steel manufacturing plants are very much related to the overall production and the efficiency of emission control measures. Nearly $43 \mathrm{Mg}$ ( $2 \% \mathrm{AEb})$ of mercury per year are released to the environment and no major changes have been reported for this sector during the 1990's and early 2000's (Pirrone et al., 2001a; Pacyna et al., 2006), whereas changes in local economies have led to changes in emissions at country level (e.g. Asia with a $10 \mathrm{Mg} \mathrm{yr}^{-1}$ increase) (Table 2).

In cement kilns, coal combustion is a significant source of mercury emissions. Mercury measurements in flue gases of cement kilns are very limited, therefore, the collection of new emissions data could be important for this source category. The evaluation of mercury emissions on the basis of emission rates should be performed keeping in mind that large differences may occur in cement kiln technology, which substantially affect the emission rates. Our estimate of mercury emissions from this particular source is based on an emission factor of $0.1 \mathrm{~g}$ per $\mathrm{Mg}$ of cement produced (Pacyna et al., 2006) and an annual cement production of $2315 \mathrm{Gg}$ (2005), which leads to $236 \mathrm{Mg} \mathrm{yr}^{-1}$ of mercury emitted to the atmosphere (10\% AEb). The uncertainty in this estimate is $\pm 30 \%$ as suggested by Streets et al. (2009b) (Table 5).

Approximately 135 chlor-alkali plants using mercury cell technology were in operation worldwide in 2007 , though in Europe after the approval of recent legislation most of plants have phased out the use of such technology and have been converted to membrane technology (WCC, 2007; Mukherjee et al., 2004). Due to the process characteristics, mercury can be emitted/released from the mercury cell process through emissions to the air, discharge of waste waters and solid wastes. The total mercury emission in Western Europe was $9.5 \mathrm{Mg}$ in 1998 , ranging from $0.2-3.0 \mathrm{~g}$ of mercury per $\mathrm{Mg}$ of chlorine capacity at the individual plants (EC, 2001a, 2002). In the literature, significant discrepancies can be found between the amount of emissions reported and the amount of mercury purchased to replace mercury in cells. This missing amount of mercury is in the range of 0.069 to $0.35 \mathrm{~kg}$ per $\mathrm{Mg}$ of $\mathrm{NaOH}$ produced; however, very different figures have been found for new emerging countries (i.e. India) where this amount is 25 times higher than that used to derive the global best estimate. Our estimate (Table 5) of mercury emissions from this industrial sector is about $163 \mathrm{Mg} \mathrm{yr}^{-1}$ (Mukherjee et al., 2009; Streets et al., 2009a).
Primary mercury production is another source of mercury released to the atmosphere. The official data on mercury production from mining is very uncertain because most countries do not report their mercury production in official statistical yearbooks. At present, productive primary mercury mines are located in Algeria, the People's Republic of China, Kyrgyzstan and Spain, whereas Italy, Mexico, Slovakia, Slovenia and Turkey retain significant reserves as a consequence of previous mining activities. In 2000, nearly $1800 \mathrm{Mg}$ of mercury were produced (Maxson, 2006) which led to a global mercury emissions of nearly $50 \mathrm{Mg} \mathrm{yr}^{-1}$ (Table 5), this estimate is considered to be very conservative because of the large uncertainty associated with both the amount of mercury and the emission factors used (Pirrone et al., 2009).

Mercury released from artisanal and small scale gold mining activities (ASGM) is one of the most critical environmental issues, because almost all activities are in developing countries and countries with economies in transition. Current estimates are derived from governments data on mercury and gold exports/imports, field reports and analysis of the production and technology used. As result, ASGM is active in 70 countries, with $1000 \mathrm{Mg} \mathrm{yr}^{-1}$ of mercury released to the environment from this particular source. Nearly $400 \mathrm{Mg} \mathrm{yr}^{-1}$ $(17 \% \mathrm{AEb})$ is the amount of mercury released to the atmosphere from ASGM , which includes $350 \mathrm{Mg} \mathrm{yr}^{-1}$ from amalgam burning and $50 \mathrm{Mg} \mathrm{yr}^{-1}$ from tailings (Telmer and Veiga, 2009) (Table 5).

Hazardous or non-hazardous waste generation is strictly related to the consumption of goods and the recycling processes adopted in the region or country. Maxson (2004) estimated that mercury use from 1994-2000 for all products and processes production has averaged $3600 \mathrm{Mg}$ per year. A recent assessment for 2005 shows that the mercury supply is in the range of $3000-3800 \mathrm{Mg} \mathrm{yr}^{-1}$ (UNEP, 2006), which is quite different from that reported by Maxson (2006). Major uses of mercury are in small-scale artisanal gold mining, vinyl chloride monomer (VCM) and chlor-alkali production, as well as in batteries, dental amalgam, electronic devices and fluorescent lamps manufacturing (Fig. 2). Mercury is also emitted through cremation, agricultural practices and other minor uses (UNEP, 2002; Maxson, 2004). The amount of mercury in solid waste depends upon the mercury content in products, the products' lifetime and waste disposal mechanisms. Knowledge of mercury in different types of wastes is scarce and this implies also that the mercury emission estimate from waste disposal practices (i.e., incinerators, landfills) is affected by a large uncertainty.

Mercury in industrial wastes originates mostly from the phasing out of mercury from industrial processes and mercury-containing products. The most important source that generates wastes containing mercury is the chlor-alkali industry. Waste from the chlorine industry contains 10 to $17 \mathrm{~g}$ of mercury per $\mathrm{Mg}$ of chlorine capacity (EC, 2001b). Chlor-alkali production based on mercury cells represents 
2000

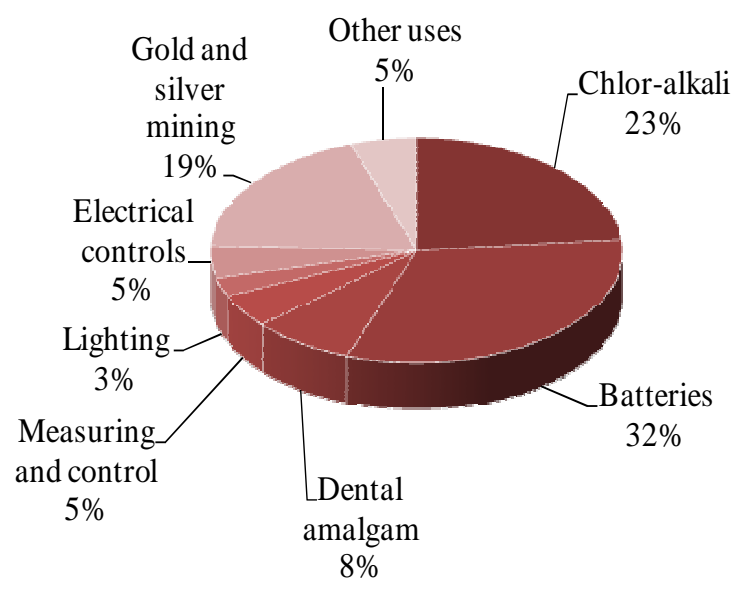

2005

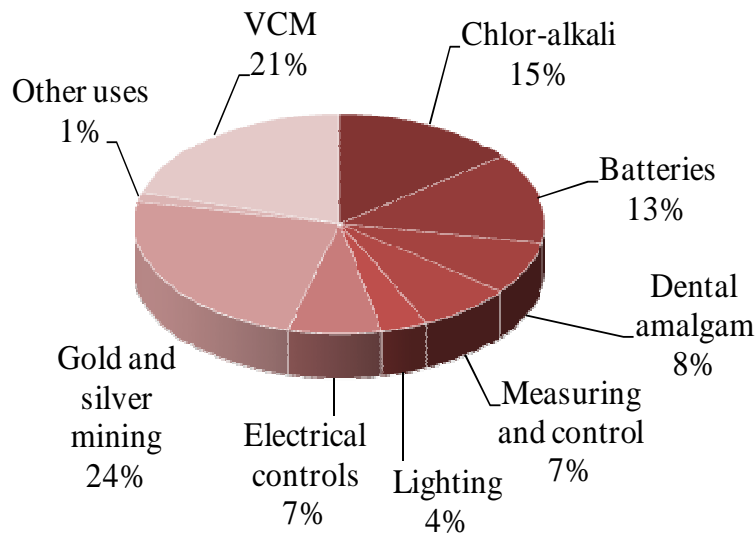

Fig. 2. Percentages of global mercury demand by use category in 2000 (a) and 2005 (b). Global demand was $3386 \mathrm{Mg}$ and $3415 \mathrm{Mg}$, respectively in 2000 and 2005 (from Maxson (2004) and UNEP (2006)).

$21 \%$ of the total world capacity. Based on the chlorine production capacity by mercury cells $(12 \mathrm{Tg})$ and the progressive reduction in the use of mercury cell technology $\left(10 \% \mathrm{yr}^{-1}\right)$, it is estimated that in 2008 mercury waste from chlor-alkali plants was between 12 and $20 \mathrm{Mg}$ with an average value of $18 \mathrm{Mg}$. Metal smelting is an additional source of waste containing mercury. The current estimate gives 9.4 Mg as upper boundary with a very low uncertainty (lower value is 8.4) (Pacyna et al., 2010). In the near future a large amount of equipment phased out from industrial processes as well as mercury-containing products are expected to become mercury-containing waste.

Mercury in municipal waste is primarily related to consumer products. Mercury is used in batteries, dental applications, measurement and electronic devices, lamps and other minor applications. The estimate of mercury release from municipal solid wastes was based on the distribution coefficients pertaining to disposal (i.e. release by breaking, incineration, landfilling, recollection) and to related emission coefficients. For some European Countries, Mukherjee et al. (2004) estimated that $240 \mathrm{Mg}$ per year is the amount of mercury in waste related to consumer products, however, mercury emissions from this sector have not been estimated yet. Slag produced from waste incineration processes could be a mercury source. It is mostly used for road construction, noise barriers, concrete production or landfill material. Slag has mercury concentration from 0.02 to $7.75 \mathrm{mg} \mathrm{kg}^{-1}$. Assuming a mercury content of $4 \mathrm{mg} \mathrm{kg}^{-1}$, the total mercury mobilized in slag from waste incinerators in Europe (EU-15 + 3 non-EU countries) varies between 24 and $54 \mathrm{Mg}$, which is partially released to the atmosphere (Mukherjee et al., 2004).

Mercury in medical waste has not been yet estimated in many countries, as a consequence a global assessment of mercury emissions from this particular source has not been made yet, and emissions are often lumped in the overall waste incinerators estimate (UNEP, 2002). In the United States, about 5000 medical waste incinerators are in operation with most of them releasing mercury that is 50 times higher than that released by a municipal solid waste incinerator (USEPA, 2008).

Summing up all contributions from the incineration of urban, medical and industrial wastes the global mercury emissions to the atmosphere from this emission source category is $187 \mathrm{Mg} \mathrm{yr}^{-1}$ (Table 5).

Coal-bed fires have occurred since prehistoric times and were initiated by natural causes including spontaneous combustion, lightning strikes and forest fires. However, they have proliferated worldwide since the Industrial Age, primarily as a consequence of anthropogenic activities (Stracher and Taylor, 2004). Today, tens of thousands of uncontrolled coal-bed fires are active in the world, which emit mercury among other compounds (Stracher, 2007). Hundreds of fires are currently active in China and the United States (Fig. 3). In China, there may be 200 coal-bed fires and in the United States more than 140 , while there may be as many as 10000 small coal-bed and peat fires in Indonesia (A. Whitehouse, personal communication, 2004). Taking into account the mean of the estimates for the amount of coal consumed annually by uncontrolled coal-bed fires (200 million Mg of which 112.5 million $\mathrm{Mg}$ in China and 87.5 million $\mathrm{Mg}$ in the rest of the World) and considering $0.16 \mathrm{~g}$ per $\mathrm{Mg}$ of coal as the average mercury content in coal, the amount of mercury released annually to the atmosphere by uncontrolled coal-bed fires is $32 \mathrm{Mg}(\sim 1 \% \mathrm{AEb})$ (Table 5). 


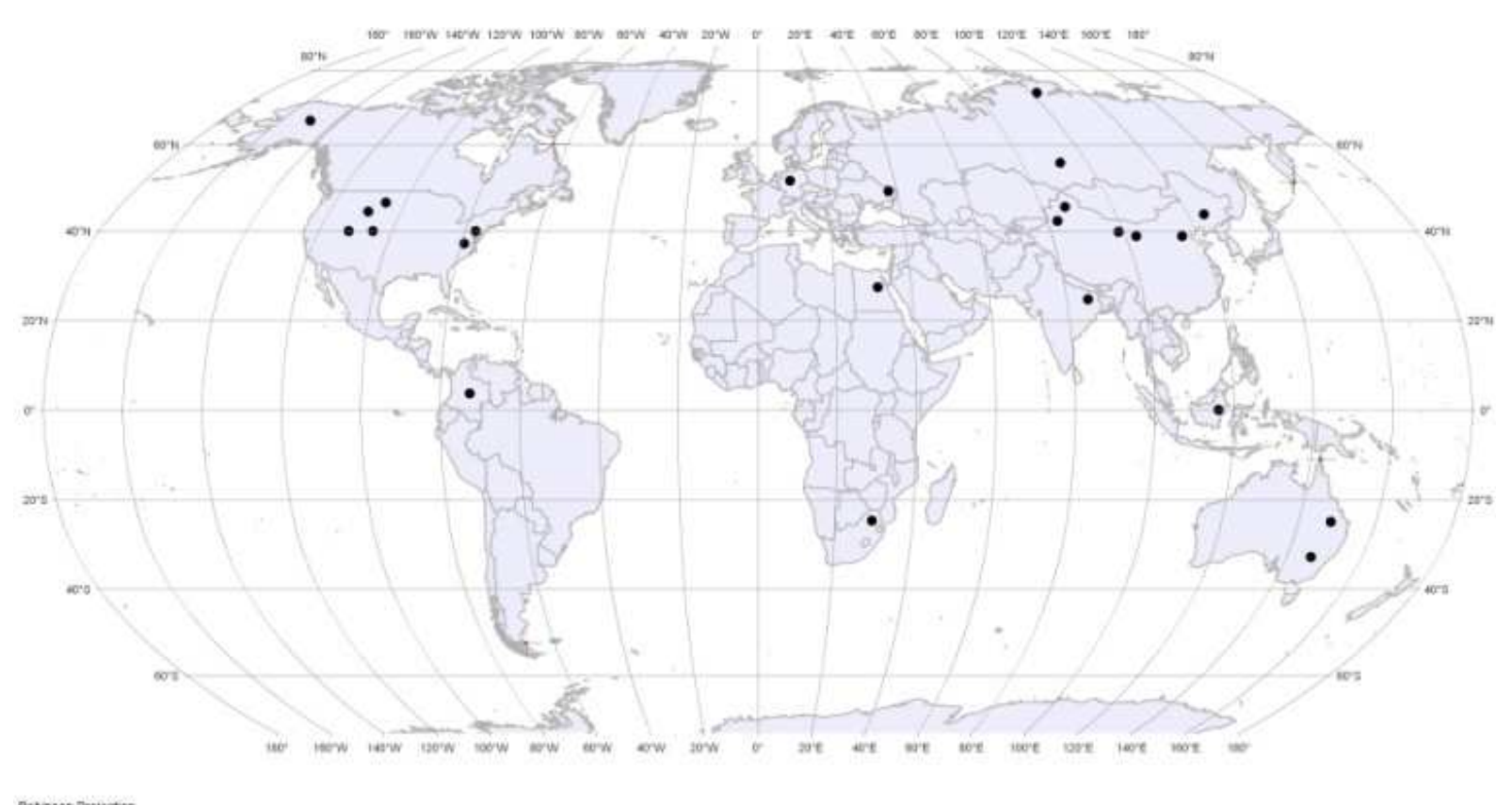

Fobmeon Frovetion
Cormai Meridan: 0.00

Fig. 3. Coal-bed fires distribution around the World (from http://www.gi.alaska.edu/ $\sim$ prakash/coalfires/global_distribution.html).

Vinyl chloride monomer (VCM) is an intermediate feedstock in the production of polyvinyl chloride (PVC). Among the two processes used to manufacture vinyl chloride, the acetylene process uses mercuric chloride on carbon pellets as a catalyst, while the other does not use mercury. In order to estimate mercury emission from PVC production, information on the precise amount of PVC resin produced by the acetylene technologies and mercury consumption/wastage per megagram of produced VCM is required. Global production of VCM in 2007 was almost $40 \mathrm{Tg}$. From 2004 to 2007, global consumption of VCM grew by about $5.5 \%$ per year as a result of strong demand for PVC, mainly for construction end-uses (Linak, 2009). Actual data on mercury consumption associated with catalyst for VCM production is fragmented. Nevertheless an investigation and calculation shows that the $\mathrm{Hg} / \mathrm{PVC}$ ratio is in the range of $0.12-0.20 \mathrm{~kg}$ mercury per $\mathrm{Mg}$ of $\mathrm{PVC}$ produced and the amount released to the atmosphere is a small fraction (0.01) (Tsinghua University, 2009). Following the methodology proposed by the Tsinghua University group (Tsinghua University, 2009), mercury emissions have been estimated from global production of PVC, which in 2007 was approximately $34 \mathrm{Tg}$. Total PVC production involving mercury catalyst was near $12 \mathrm{Tg}(35 \%)$ accounting for $24 \mathrm{Mg}$ of mercury released to the atmosphere (Table 5).

Previous studies have not paid too much attention to mercury emissions from mobile sources. Recent estimates in the United States indicate that the overall emissions are relatively small compared to other emission source categories. For example, in the USA National Emissions Inventory (NEI) for 2002 , it is reported that less than $1 \mathrm{Mg}$ of mercury per year is emitted from mobile sources (highway vehicles, construction vehicles, recreational boats and aircrafts), which is less than $1 \%$ of the total mercury emission of the country (USEPA, 2005). Nevertheless, a significant effort has been made to assess mercury emissions from vehicular traffic (Conaway et al., 2005; Landis et al., 2007). A very conservative global assessment of mercury emissions from petroleum fuel consumption for 2000 was made recently by considering emission factors reported in literature and the world consumption of petrol and diesel (Pirrone et al., 2009). Petrol combustion contributed with $238 \mathrm{~kg} \mathrm{yr}^{-1}\left(121-281 \mathrm{~kg} \mathrm{yr}^{-1}\right)$ of mercury emissions, while diesel contributed $140 \mathrm{~kg} \mathrm{yr}^{-1}$ $\left(71-209 \mathrm{~kg} \mathrm{yr}^{-1}\right)$. The total mercury emission was around $378 \mathrm{~kg} \mathrm{yr}^{-1}\left(192-564 \mathrm{~kg} \mathrm{yr}^{-1}\right)$ with a growing trend due to the increase of gasoline and diesel consumption. Region by region, North America released $156 \mathrm{~kg}$, followed by Asia $(94 \mathrm{~kg})$ and Europe $(80 \mathrm{~kg})$. The global contribution from petroleum fuels combustion represented $0.00013 \%$ on $\mathrm{AEb}$ and can be neglected in our global assessment, however, our current estimate does not consider the contribution from fuel consumption in the shipping, aviation and military sectors and it does not account for the contribution related to the combustion of biodiesels.

In the last decades a considerable amount of research has been done to improve mercury emission inventories at country level, including those countries with economies in transition (Feng et al., 2009; Streets et al., 2009a). In Europe, 
mercury emissions from anthropogenic sources in the year 2005 were near $145 \mathrm{Mg}$, with the highest contribution from stationary combustion sources (52\%). The second contributing category consisted of several industrial sectors, including chlor-alkali production, ferrous and non-ferrous metal production and cement production (38\%), whereas other sources, including waste incinerators and emissions from various mercury uses, account for about $10 \%$ of the total.

Coal combustion and the incineration of solid waste account for most mercury emissions in the United States (USEPA, 2005), whereas smelters for non-ferrous metal production accounts for most of the mercury emissions in Canada and Mexico (CEC, 2001; Canada, 2008). The total anthropogenic mercury emission from North America is estimated to be $153 \mathrm{Mg} \mathrm{yr}^{-1}$, which is lower than that reported in the previous regional and worldwide estimates (that assumed 1996 as the reference year) in which North American emissions ranged from $240 \mathrm{Mg} \mathrm{yr}^{-1}$ to $333 \mathrm{Mg} \mathrm{yr}^{-1}$ (Pirrone et al., 1996, 1998) (Table 5).

According to the official data, the total emission of mercury from Russian facilities was $2.9 \mathrm{Mg}$ in 2001. Besides this information, a significant amount of mercury is released from area sources and from processes in which mercury is present as a natural impurity in the raw materials. The total Russian anthropogenic emissions are estimated to be $70 \mathrm{Mg} \mathrm{yr}^{-1}$, with $77 \%$ being the contribution from processes where mercury is mobilized as an impurity (ACAP, 2005) (Table 5).

Mercury emissions in China were estimated to be $609 \mathrm{Mg}$ in 2003, with a large fraction (44\%) due to coal combustion, which in China includes three major subcategories: coalfired power plants, industrial boilers and residential uses. Emissions from these categories increased from $202 \mathrm{Mg}$ in 1995 to $334 \mathrm{Mg}$ in 2005 (with the largest contribution from power plants and manufacturing industries) (Streets et al., 2009a). As China is the largest coal producer and consumer in the world, mercury emissions in China have been increasing rapidly in recent years and are receiving increasing attention (Wu et al., 2006; Wang et al., 2010). By 2007, coal consumption by power generation in China increased to 1.49 billion tons, indicating a even higher annual growth rate during 2004-2007 (5.9\%) (Wu et al., 2006). In addition, approximately $33 \%$ of the mercury is released from non-ferrous metals smelters (Feng et al., 2009). The emissions from cement production facilities $(6 \%)$ and mercury mines (5\%) represent a minor contribution. The mercury emissions from biomass burning was nearly $14 \mathrm{Mg} \mathrm{yr}^{-1}$, whereas spontaneous burning in coal mines accounts for $3 \mathrm{Mg} \mathrm{yr}^{-1}$ as reported by Streets and colleagues (2005; 2009a) (Table 5).

In Australia, the total mercury emission from anthropogenic sources is $16.6 \mathrm{Mg} \mathrm{yr}^{-1}$ with coal-fired power plants $\left(2.2 \mathrm{Mg} \mathrm{yr}^{-1}\right)$ and non-ferrous metal smelters $\left(11.6 \mathrm{Mg} \mathrm{yr}^{-1}\right)$ representing the major emission sources (Nelson, 2007). This estimate is larger than that reported in the National Pollution Inventory $\left(1.1 \mathrm{Mg} \mathrm{yr}^{-1}\right)$, and significantly lower than that reported in the GMA (97 $\mathrm{Mg} \mathrm{yr}^{-1}$ ) (UNEP, 2002), however, it is in relatively good agreement with the earlier estimate of 6.3-8.6 $\mathrm{Mg} \mathrm{yr}^{-1}$ reported in Pirrone et al. (1996) for the period of 1983 to 1992 (Table 5).

Mercury contamination is widespread in India and a recent study (Mukherjee et al., 2009) has dealt with industrial emissions of mercury from coal combustion, the iron and steel industry, non-ferrous metallurgical plants, chloralkali plants, the cement industry, waste disposal and others minor sources (i.e. brick manufacturing). No information was found in the literature for the pulp and paper industry or for the oil and petrochemical industry in India. The highest contributing source categories are coal combustion (52\%) and waste disposal through incineration (32\%). Industrial mercury emissions in India have decreased from $321 \mathrm{Mg}$ in 2000 to $241 \mathrm{Mg}$ in 2004. The Ministry of Environment and Forest in New Delhi has reported that $86 \%$ of mercury-cell chlorine plants have been converted to membrane technology (Mukherjee et al., 2009). This change suggests that mercury emissions have decreased from $132 \mathrm{Mg}$ in 2000 to $6.2 \mathrm{Mg}$ in 2004 (Table 5).

Limited information is available for African countries in relation to emissions from anthropogenic sources and mercury content in products, however, several studies have been carried out in South Africa in developing an emission inventory for major anthropogenic sources (Leaner et al., 2009). Nevertheless most of mercury released in the environment originates from artisanal gold mining activities (Telmer and Veiga, 2009). The country is a primary producer of important and strategic metals (e.g. gold, platinum, lead, zinc) and is a major producer and consumer of coal in Africa. Although the production facilities of these minerals and materials are known for their contribution to mercury pollution, detailed mercury emission inventories for these sources are not yet fully developed (Leaner et al., 2009). Leaner and colleagues critically revised previous estimates, giving an estimates for the country of about $40 \mathrm{Mg} \mathrm{yr}^{-1}$ (Leaner et al., 2009). Most of the mercury emissions are related to electric power generation facilities that account for $81 \%$ of the total national emission (Dabrowski et al., 2008). The coal gasification process accounts for $4 \%$ of the total, whereas coal combustion in cement kilns and producing clinker is the major source of mercury in cement production, representing $9 \%$ of the total emission (Table 5).

In Brazil, the amount of mercury entering the environment was estimated to be about $200 \mathrm{Mg} \mathrm{yr}^{-1}$ (Trade and Environment Database (TED) case 132). Gold recovery is performed by removing sediments from river bottoms and adjacent areas and feeding them through a number of mercury-coated sieves. Roughly $1.0 \mathrm{~kg}$ of mercury enters the environment for every kilogram of gold produced by artisans (Telmer and Veiga, 2009). Another estimate in the Alta Floresta area, Brazil, shows that a typical month's gold production of $230 \mathrm{~kg}$ emitted $240 \mathrm{~kg}$ of mercury to the atmosphere as elemental mercury vapor and $60 \mathrm{~kg}$ of mercury into rivers. In 
1990

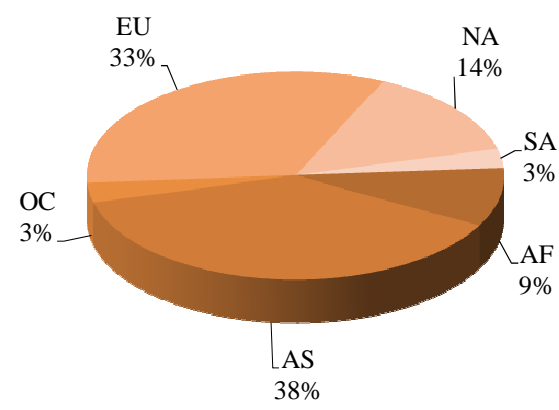

2000

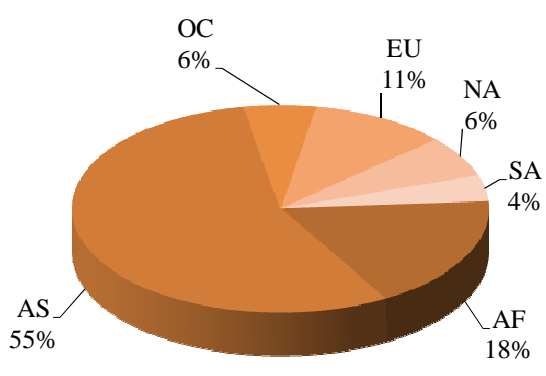

1995

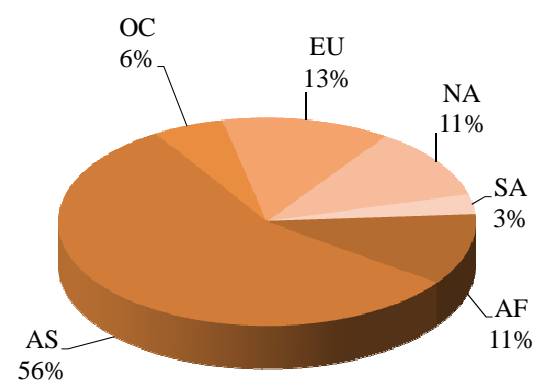

2007

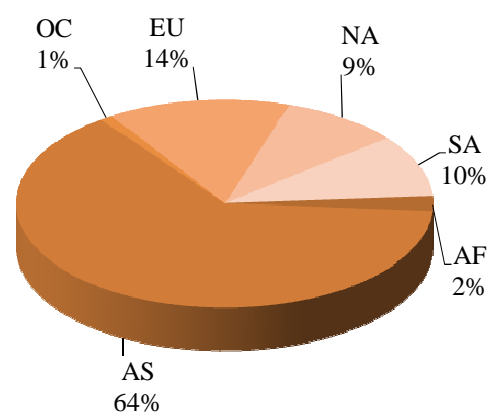

Fig. 4. Trends of global anthropogenic emissions by region based on Pirrone et al. (1996) (a), Pacyna et al. (2003) (b), Pacyna et al. (2006) (c) and this work (d). Data reported in Fig. 3d are for most contributing countries as reported in Table 2 AF, Africa; AS, Asia; EU, Europe; NA, North America; OC, Oceania; SA, South America.

addition, emissions of mercury from coal fired power plants is about $5.6 \mathrm{Mg} \mathrm{yr}^{-1}$ (emission factor $0.2 \mathrm{mg} \mathrm{kg}^{-1}$ ) with a coal consumption of about $28 \mathrm{Tg} \mathrm{yr}^{-1}$ (Mukherjee et al., 2009) (Table 5).

Our current estimate suggests that summing up the contributions from anthropogenic sources, nearly $2320 \mathrm{Mg}$ of mercury is released annually to the global atmosphere (31\% GEb) (Table 6). The present assessment shows that the majority of mercury emissions originate from combustion of fossil fuels (11\% GEb), followed by artisanal small scale gold mining $(5 \% \mathrm{GEb})$, non-ferrous metal production $(4 \%$ $\mathrm{GEb})$, cement production ( $3 \% \mathrm{GEb}$ ), caustic soda production $(2 \% \mathrm{GEb})$, waste incineration $(2 \% \mathrm{GEb})$ and pig-iron production $(1 \% \mathrm{GEb})$.

A comparison of our estimates with those reported in the literature (Fig. 4) suggests that Europe and North America are reducing their contribution to the global mercury burden, whereas emissions in Asia are increasing, the latter is primarily driven by the upward trend of energy demand that in the last decade has grown at a rate of 6 to $10 \%$ per year.
Table 6. Global mercury emissions from anthropogenic sources.

\begin{tabular}{|c|c|c|}
\hline Source category & $\begin{array}{l}\mathrm{Hg} \text { emission } \\
\left(\mathrm{Mg} \mathrm{yr}^{-1}\right)\end{array}$ & Reference \\
\hline Coal and oil combustion & 810 & This work \\
\hline Non-ferrous metal prod. & 310 & (USGS, 2004) \\
\hline Pig iron and steel prod. & 43 & $\begin{array}{l}\text { (Pirrone et al., 2001b; } \\
\text { Pacyna et al., 2006) }\end{array}$ \\
\hline Cement production & 236 & This work \\
\hline Caustic soda production & 163 & This work \\
\hline Mercury production & 50 & This work \\
\hline $\begin{array}{l}\text { Artisanal gold mining } \\
\text { prod. }\end{array}$ & 400 & $\begin{array}{l}\text { (Telmer and Veiga, } \\
\text { 2009) }\end{array}$ \\
\hline Waste disposal & 187 & This work \\
\hline Coal bed fires & 32 & This work \\
\hline VCM production & 24 & This work \\
\hline Other & 65 & This work \\
\hline TOTAL & 2320 & \\
\hline
\end{tabular}


As widely recognized, mercury emission estimates are subjected to uncertainty (Pacyna et al., 2003; Streets et al., 2005; Lindberg et al., 2007; Wu et al., 2006; Swain et al., 2007; Wu et al., 2010). The primary methodology used for the uncertainty assessment was described in the work of Streets et al. (2003). Although estimates of current anthropogenic emissions for many other pollutants are cited with a greater precision, an uncertainty of $\pm 30 \%$ for major industrial sources of mercury is widely accepted (Pacyna et al., 2010). Mercury emission estimates are directly related to the emission factors and activity levels ascribed to major anthropogenic activities, and the uncertainties in these two factors have an additive influence on the overall uncertainty associated with emission estimates (Pirrone et al., 2010). In detail, uncertainty for stationary fossil fuel combustion is $25 \%$ while that for non-ferrous metal, iron and steel and cement production is $30 \%$ (Pacyna et al., 2010).

In addition, a specific concern is for regions that are inadequately described in terms of point sources or exhibit unusually high uncertainties. Pacyna et al. (2010), suggested that emission estimates can be 27\% for North America, 30\% for Australia and Europe and 50\% for Africa and South America.

\section{Further research}

The uncertainty of anthropogenic emission estimates is mostly related to rapid economic development in emerging economies, particularly in South and South-East Asia in which the impact of fossil fuel use in energy production is twofold. Firstly because fossil fuel power plants are the single most important anthropogenic mercury emission to the atmosphere, secondly because the other pollutants emitted as a result of fossil fuel combustion such as $\mathrm{NO}_{\mathrm{x}}$ and $\mathrm{SO}_{2}$ play an important role in the atmospheric chemistry of mercury and influence its local deposition patterns. A specific concern is for regions that are inadequately described in terms of point sources (Africa, South America) or exhibit unusually large uncertainties (Asia). These uncertainties affect model development, environmental policy and human welfare.

Atmospheric mercury models developed in recent years for assessing the relationship between emission source regions and receptor regions show a limited accuracy. The ability to determine the accuracy of current models is severely limited by the lack of a unified global emission inventory that includes an improved emission source characterization related to fossil fuel power plants in fast developing countries where energy demand is projected to continue to follow an upward trend in the next decade.

The improvement of the mercury emission inventory on a global scale, with special attention to fossil fuel-fired power plants in countries characterized by fast economic growth (i.e., China, India) will lead to a better assessment of the impact of different energy production strategies foreseen in ma- jor environmental outlooks elaborated by leading institutions such as the UNEP, World Bank, Worldwatch Institute and International Energy Agency. Detailed mercury emission inventories at regional and global scales may help nations to shape future energy management strategies that, among others, will lead to a better assessment of countries' potential for renewable and non-renewable energy production; this is in agreement with recommendations and requirements of major international conventions and programs aimed to reduce the impact of anthropogenic pressures on ecosystems and human health.

The emission of mercury to the atmosphere driven by natural processes represents an important part of the global atmospheric mercury budget and is a dominant part of the global mercury cycle. However, while there is an on-going and continued effort to quantify these fluxes, the magnitude of their extent, including both primary and secondary (recycled) sources, is still poorly constrained.

Edited by: R. Ebinghaus

\section{References}

ACAP: Assessment of Mercury Releases from the Russian Federation, Tech. rep., Arctic Council Action Plan to Eliminate Pollution of the Arctic (ACAP), Copenhagen, Denmark, 2005.

AMAP/UNEP: Technical Background Report to the Global Atmospheric Mercury Assessment, Tech. rep., Arctic Monitoring and Assessment Programme / UNEP Chemicals Branch, 2008.

Bagnato, E., Allard, P., Parello, F., Aiuppa, A., Calabrese, S., and Hammouya, G.: Mercury gas emissions from La Soufrière Volcano, Guadeloupe Island (Lesser Antilles), Chem. Geol., 266, 267-273, 2009a.

Bagnato, E., Parello, F., Valenza, M., and Caliro, S.: Mercury content and speciation in the Phlegrean Fields volcanic complex: Evidence from hydrothermal system and fumaroles, J. Volcanol. Geothermal Res., 187, 250-260, 2009b.

Bullock, O. R. and Jaeglé, L.: Importance of a global scale approach to using regional models in the assessment of source-receptor relationships for mercury, Springer, New York, USA, chap. 16, 503-517, 2009.

Canada, E.: National Pollutant Release Inventory, Tech. rep., Environment Canada, www.ec.gc.ca., 2008.

CEC: Preliminary Atmospheric Emissions Inventory of Mercury in Mexico, Tech. Rep. 3.2.1.04., Acosta y Asociados Project, 2001.

Cinnirella, S. and Pirrone, N.: Spatial and temporal distributions of mercury emissions from forest fires in Mediterranean region and Russian federation, Atmos. Environ., 40, 7346-7361, 2006.

Cinnirella, S., Pirrone, N., Allegrini, A., and Guglietta, D.: Modeling mercury emissions from forest fires in the Mediterranean region, Environ. Fluid Mech., 8, 129-145, 2008.

Conaway, C. H., Mason, R. P., Steding, D. J., and Flegal, A. R.: Estimate of mercury emission from gasoline and diesel fuel consumption, San Francisco Bay area, California, Atmos. Environ., 39, 101-105, 2005.

Dabrowski, J. M., Ashton, P. J., Murray, K., Leaner, J. J., and Mason, R. P.: Anthropogenic mercury emissions in South Africa: 
Coal combustion in power plants, Atmos. Environ., 42, 66206626, 2008.

Dastoor, A. P. and Davignon, D.: Global mercury modelling at Environment Canada, Springer, New York, USA, chap. 17, 519532, 2009.

Ebinghaus, R., Slemr, F., Brenninkmeijer, C. A. M., van Velthoven, P., Zahn, A., Hermann, M., O'Sullivan, D. A., and Oram, D. E.: Emissions of gaseous mercury from biomass burning in South America in 2005 observed during CARIBIC flights, Geophys. Res. Lett., 34, L08813, doi:10.1029/2006GL028866, 2007.

EC: Integrated Pollution Prevention and Control (IPPC) Reference Document on Best Available Techniques in the Chlor-Alkali Manufacturing industry, Tech. rep., European Commision, Brussels, eippcb.jrc.es, 2001a.

EC: Pollutants in urban waste water and sewage sludge, Tech. rep., European Commision, Luxemburg, www.ec.europa.eu/ environment/waste/sludge/sludge $\backslash$ pollutants.htm, 2001b.

EC: Final report from the Commission of the Council concerning mercury from the Chlor-Alkali Industry, Tech. rep., European Commision, Brussels, 2002.

EEA: EMEP/EEA air pollutant emission inventory guidebook 2009, Tech. Rep. 9, European Environment Agency, www.eea.europa. eu/publications/emep-eea-emission-inventory-guidebook-2009, 2009.

EIA: International Energy Outlook 2009, Tech. rep., Energy Information Administration, www.eia.doe.gov/oiaf/archive/ieo09/ index.html, 2009.

Ericksen, J. A. and Gustin, M. S.: Foliar exchange of mercury as a function of soil and air mercury concentrations, Sci. Total Environ., 324, 271-279, 2004.

Ericksen, J. A., Gustin, M. S., Schorran, D. E., Johnson, D. W., Lindberg, S. E., and Coleman, J. S.: Accumulation of atmospheric mercury in forest foliage, Atmos. Environ., 37, 16131622, 2003.

Feng, X., Streets, D., Hao, J., Wu, Y., and Li, G.: Mercury emissions from industrial sources in China, Springer, New York, USA, chap. 3, 67-79, 2009.

Ferrara, R., Mazzolai, B., Lanzillotta, E., Nucaro, E., and Pirrone, N.: Volcanoes as emission sources of atmospheric mercury in the Mediterranean basin, Sci. Total Environ., 259, 115-121, 2000.

Friedli, H., Arellano, A., Cinnirella, S., and Pirrone, N.: Initial Estimates of Mercury Emissions to the Atmosphere from Global Biomass Burning, Environ/ Sci. Technol., 43, 3507-3513, 2009a.

Friedli, H. R., Radke, L. F., Lu, J. Y., Banic, C. M., Leaitch, W. R., and MacPherson, J. I.: Mercury emissions from burning of biomass from temperate North American forests: laboratory and airborne measurements, Atmos. Environ., 37, 253-267, 2003.

Friedli, H. R., Arellano, A. F., Cinnirella, S., and Pirrone, N.: Mercury emissions from global biomass burning: spatialand temporal distribution, Springer, New York, USA, chap. 8, 193-220, 2009b.

Gustin, M. S., Lindberg, S. E., Austin, K., Coolbaugh, M., Vette, A., and Zhang, H.: Assessing the contribution of natural sources to regional atmospheric mercury budgets, Sci. Total Environ., 259, 61-71, 2000.

Hedgecock, I. M., Pirrone, N., Trunfio, G. A., and Sprovieri, F.: Integrated mercury cycling, transport, and air-water exchange (MECAWEx) model, J. Geophys. Res., 111, D20302, doi:10.1029/2006JD007117, 2006.
Hylander, L. D. and Herbert, R. B.: Global Emission and Production of Mercury during the Pyrometallurgical Extraction of Nonferrous Sulfide Ores, Environ. Sci. Technol., 42, 5971-5977, online available at: http://dx.doi.org/10.1021/es800495g, 2008.

Jaeglé, L., Strode, S. A., Selin, N. E., and Jacob, D. J.: The GeosChem model, Springer, New York, USA, chap. 18, 533-545, 2009.

Jung, G., Hedgecock, I. M., and Pirrone, N.: The ECHMERT model, Springer, New York, USA, chap. 19, 547-569, 2009.

Karlsen, A., Tewalt, S., Bragg, L., and Finkelman, R.: The world coal quality inventory: South America., Open-File Report 1241, na, 2006.

Lacerda, L.: Amazon mercury emissions, Nature, 374, 20-21., 1995.

Landis, M. S., Lewis, C. W., Stevens, R. K., Keeler, G. J., Dvonch, J. T., and Tremblay, R. T.: Ft. McHenry tunnel study: Source profiles and mercury emissions from diesel and gasoline powered vehicles, Atmos. Environ., 41, 8711-8724, 2007.

Leaner, J. J., Dabrowski, J. M., Mason, R. P., Resane, T., Richardson, M., Ginster, M., Gericke, G., Petersen, C. R., Masekoameng, E., Ashton, P. J., and Murray, K.: Mercury emissions from point sources in South Africa, Springer, New York, USA, chap. 5, 113-130, 2009.

Linak, E.: Chemical Economics Handbook on VCM, chap. 1, p. 100, SRI Consulting, www.sriconsulting.com/CEH/Public/ Reports/696.6000/, 2009.

Lindberg, S., Bullock, R., Ebinghaus, R., Engstrom, D., Feng, X., Fitzgerald, W., Pirrone, N., Prestbo, E., and Seigneur, C.: A Synthesis of Progress and Uncertainties in Attributing the Sources of Mercury in Deposition, AMBIO: J. Human Environ., 36, 19-33, 2007.

Lodenius, M.: Dry and wet deposition of mercury near a chloralkali plant, Sci. Total Environ., 213, 53-56, 1998.

Lodenius, M., Tulisalo, E., and Soltanpour-Gargari, A.: Exchange of mercury between atmosphere and vegetation under contaminated conditions, Sci. Total Environ., 304, 169-174, 2003.

Mason, R. P.: Mercury emissions from natural processes and their importance in the global mercury cycle, Springer, New York, USA, chap. 7, 173-191, 2009.

Mason, R. P. and Sheu, G.-R.: Role of the ocean in the global mercury cycle, Global Biogeochem. Cy., 16, 1093, doi:10.1029/2001GB001440, 2002.

Maxson, P.: Mercury flows in Europe and the World: the impact of decommissioned chlor-alkali plants, Tech. rep., Sprl Concorde, ec.europa.eu/environment/chemicals/mercury, 2004.

Maxson, P.: Mercury flows and safe storage of surplus mercury, Tech. rep., Sprl Concorde, ec.europa.eu/environment/chemicals/ mercury, 2006.

Mukherjee, A. B., Zevenhoven, R., Brodersen, J., Hylander, L. D., and Bhattacharya, P.: Mercury in waste in the European Union: sources, disposal methods and risks, Resources, Conserv. Recycl., 42, 155-182, 2004.

Mukherjee, A. B., Zevenhoven, R., Bhattacharya, P., Sajwan, K. S., and Kikuchi, R.: Mercury flow via coal and coal utilization byproducts: A global perspective, Resources, Conserv. Recycl., 52, 571-591, 2008.

Mukherjee, A. B., Bhattacharya, P., Sarkar, A., and Zevenhoven, R.: Mercury emissions from industrial sources in India and its effects in the environment, Springer, New York, USA, chap. 4, 
81-112, 2009.

Nacht, D. M. and Gustin, M. S.: Mercury Emissions from Background and Altered Geologic Units Throughout Nevada, Water Air Soil Pollut., 151, 179-193, 2004.

Nelson, P. F.: Atmospheric emissions of mercury from Australian point sources, Atmos. Environ., 41, 1717-1724, 2007.

Nriagu, J. and Becker, C.: Volcanic emissions of mercury to the atmosphere: global and regional inventories, Sci. Total Environ., 304, 3-12, 2003.

Nriagu, J. and Pacyna, J.: Quantitative assessment of worldwide contamination of air, water and soils by trace metals, Nature, 333, 134-139., 1988.

Pacyna, E., Pacyna, J., Sundseth, K., Munthe, J., Kindbom, K., Wilson, S., Steenhuisen, F., and Maxson, P.: Global emission of mercury to the atmosphere from anthropogenic sources in 2005 and projections to 2020, Atmos. Environ., 4, 2487-2499, 2010.

Pacyna, E. G., Pacyna, J. M., Steenhuisen, F., and Wilson, S.: Global anthropogenic mercury emission inventory for 2000, Atmos. Environ., 40, 4048-4063, 2006.

Pacyna, J. M., Pacyna, E. G., Steenhuisen, F., and Wilson, S.: Mapping 1995 global anthropogenic emissions of mercury, dynamic processes of mercury and other trace contaminants in the marine boundary layer of european seas - ELOISE II, Atmos. Environ., 37, 109-117, 2003.

Pacyna, J. M., Pacyna, E. G., and Aas, W.: Changes of emissions and atmospheric deposition of mercury, lead, and cadmium, Fifty Years of Endeavour, Atmos. Environ., 43, 117-127, 2009.

Pirrone, N., Keeler, G. J., and Nriagu, J. O.: Regional differences in worldwide emissions of mercury to the atmosphere, Atmos. Environ., 30, 2981-2987, 1996.

Pirrone, N., Allegrini, I., Keeler, G. J., Nriagu, J. O., Rossmann, R., and Robbins, J. A.: Historical atmospheric mercury emissions and depositions in North America compared to mercury accumulations in sedimentary records, atmospheric Transport, Chemistry and Deposition of Mercury, Atmos. Environ., 32, 929-940, 1998.

Pirrone, N., Costa, P., Pacyna, J. M., and Ferrara, R.: Mercury emissions to the atmosphere from natural and anthropogenic sources in the Mediterranean region, Atmos. Environ., 35, 2997-3006, 2001a.

Pirrone, N., Munthe, J., Barregård, L., Ehrlich, H., Petersen, G., Fernandez, R., Hansen, J., Grandjean, P., Horvat, M., Steinnes, E., Ahrens, R., Pacyna, J., Borowiak, A., Boffetta, P., and Wichmann-Fiebig, M.: Ambient Air Pollution by Mercury $(\mathrm{Hg})$ - Position Paper, Tech. rep., European Commision, Bruxelles, europa.eu.int/comm/environment/ air/background.htm\#mercury, 2001b.

Pirrone, N., Pacyna, J. M., and Barth, H.: Atmospheric Mercury Research in Europe, Atmos. Environ., 35, 2997-3006, 2001c.

Pirrone, N., Ferrara, R., Hedgecock, I. M., Kallos, G., Mamane, Y., Munthe, J., Pacyna, J. M., Pytharoulis, I., Sprovieri, F., Voudouri, A., and Wangberg, I.: Dynamic processes of mercury over the Mediterranean region: results from the Mediterranean Atmospheric Mercury Cycle System (MAMCS) project, dynamic processes of mercury and other trace contaminants in the marine boundary layer of european seas -=- ELOISE II, Atmos. Environ., 37, S21-S39, 2003.

Pirrone, N., Sprovieri, F., Hedgecock, I. M., Trunfio, G. A., and Cinnirella, S.: Dynamic Processes of Atmospheric $\mathrm{Hg}$ in the
Mediterranean Region, Springer, chap. 23, 541-579, 2005.

Pirrone, N., Cinnirella, S., Feng, X., Finkelman, R. B., Friedli, H. R., Leaner, J., Mason, R., Mukherjee, A. B., Stracher, G., Streets, D. G., and Telmer, K.: Global Mercury Emissions to the Atmosphere from Natural and Anthropogenic Sources, Springer, New York, USA, chap. 1, 3-49, 2009.

Pirrone, N., Cinnirella, S., Feng, X., Friedli, H. R., Levine, L., Pacyna, J., Pacyna, E. G., Streets, D. G., and Sundseth, K.: HTAP 2010 Assessment Report - Emissions and Projections, Tech. Rep. Chapter B3, LRTAP - Task Force on Hemispheric Transport of Air Pollutants, http://htap.icg.fz-juelich.de/ data/ChapterB3, 2010.

Pyle, D. M. and Mather, T. A.: The importance of volcanic emissions for the global atmospheric mercury cycle, Atmos. Environ., 37, 5115-5124, 2003.

Rea, A. W., Lindberg, S. E., Scherbatskoy, T., and Keeler, G. J.: Mercury Accumulation in Foliage over Time in Two Northern Mixed-HardwoodForests, Water, Air, \& Soil Pollution, 133, 4967, 2002.

Seigneur, C., Vijayaraghavan, K., Lohman, K., and Levin, L.: The AER/EPRI global chemical transport model for mercury (CTMHG), Springer, New York, USA, chap. 21, 589-602,2009.

Stracher, G.: Coal fires burning around the world: Opportunity for innovative and interdisciplinary research, GSA Today, Int. J. Coal Geol., 17, 36-37, 2007.

Stracher, G. and Taylor, T.: Coal fires burning out of control around the world: thermodynamic recipe for environmental catastrophe, Elsevier, 59(1-2) 7-17, 2004.

Streets, D. G., Bond, T. C., Carmichael, G. R., Fernandes, S. D., Fu, Q., He, D., Klimont, Z., Nelson, S. M., Tsai, N. Y., Wang, M. Q., Woo, J.-H., and Yarber, K. F.: An inventory of gaseous and primary aerosol emissions in Asia in the year 2000, J. Geophys. Res., 108, 8809, doi:10.1029/2002JD003093, 2003.

Streets, D. G., Hao, J., Wu, Y., Jiang, J., Chan, M., Tian, H., and Feng, X.: Anthropogenic mercury emissions in China, Atmos. Environ., 39, 7789-7806, 2005.

Streets, D. G., Hao, J., Wang, S., and Wu, Y.: Mercury emissions from coal combustion in China, Springer, New York, USA, chap. 2, 51-65, 2009a.

Streets, D. G., Zhang, Q., and Wu, Y.: Projections of Global Mercury Emissions in 2050, Environ. Sci. Technol., 43, 2983-2988, 2009b.

Swain, E. B., Jakus, P. M., Rice, G., Lupi, F., Maxson, P. A., Pacyna, J. M., Penn, A., Spiegel, S. J., and Veiga, M. M.: Socioeconomic Consequences of Mercury Use and Pollution, AMBIO: J. Human Environ., 36, 45-61, 2007.

Telmer, K. H. and Veiga, M. M.: World emissions of mercury from artisanal and small scale gold mining, Springer, New York, USA, 131-172, 2009.

Tewalt, S. and Finkelman, L. B. R.: Mercury in U.S. coal: abundance, distribution and modes of occurrence, Fact Sheet FS-09501, U.S. Geological Survey, http://pubs.usgs.gov/fs/fs095-01/, 2001.

Toole-O’Neil, B., Tewalt, S. J., Finkelman, R. B., and Akers, D. J.: Mercury concentration in coal-unraveling the puzzle, Fuel, 78, 47-54, 1999.

Travnikov, O. and Ilyin, I.: The EMEP/MSC-E mercury modeling system, Springer, New York, USA, chap. 20, 571-587, 2009.

Tsinghua University: Improve the Estimates of Anthropogenic 
Mercury Emissions in China, Tech. rep., Tsinghua University, www.chem.unep.ch/MERCURY/, 2009.

UNEP: Global Mercury Assessment, Tech. rep., UNEP, Geneva, Switzerland, www.chem.unep.ch/MERCURY/, 2002.

UNEP: Summary of Supply, Trade and Demand Information on Mercury, Tech. rep., ENEP, Geneva, Swizerland, www.chem. unep.ch/MERCURY, 2006.

USEPA: Mercury study report to congress, EPA-452/R-97-010 VIII, United States Environmental Protection Agency, Washington, DC, USA, www.epa.gov, 1997.

USEPA: Control of mercury emissions from coal-fired electric utility boilers, Tech. Rep. EPA-600/R-01-109, US Environmental Protection Agency, Washington, DC, USA, 2002a.

USEPA: ICR data, Tech. rep., US Environmental Protection Agency, http://www.epa.gov/ttn/atw/combust/utiltox/icrdata.xls, 2002b.

USEPA: National Emission Inventory (NEI), Tech. rep., US EPA, www.epa.gov, 2005.

USEPA: Mercury in medical waste. Mercury fact sheet $n .1$, Tech. rep., Environmental Protection Agency, Region 5, Air and radiation Division., www.epa.gov/nscep/, 2008.

USGS: Minerals yearbook, Tech. rep., US Geological Survey, http://minerals.usgs.gov/minerals/pubs/commodity/mercury/ index.html\#myb, 2004.

Veiga, M. M., Maxson, P. A., and Hylander, L. D.: Origin and consumption of mercury in small-scale gold mining, Journal of Cleaner Production, 14, 436 - 447, improving Environmental, Economic and Ethical Performance in the Mining Industry. Part 1, Environ. Manage. Sustain. Develop., 2006.
Wang, Q., Shen, W., and Ma, Z.: Estimation of mercury emission from coal combustion in China, Environ. Sci. Technol., 34, 2711-2713, 2000.

Wang, S. X., Zhang, L., Li, G. H., Wu, Y., Hao, J. M., Pirrone, N., Sprovieri, F., and Ancora, M. P.: Mercury emission and speciation of coal-fired power plants in China, Atmos. Chem. Phys., 10, 1183-1192, doi:10.5194/acp-10-1183-2010, 2010.

WCC: Sustainability Commitments and Actions, Tech. rep., World Chlorine Council, 2007.

Wiedinmyer, C. and Friedli, H.: Mercury Emission Estimates from Fires: An Initial Inventory for the United States, Environ. Sci. Technol., 41, 8092-8098, 2007.

Wilhelm, S. M.: Estimate of Mercury Emissions to the Atmosphere from Petroleum, Environ. Sci. Technol., 35, 4704-4710, 2001.

Wu, Y., Wang, S., Streets, D. G., Hao, J., Chan, M., and Jiang, J.: Trends in Anthropogenic Mercury Emissions in China from 1995 to 2003, Environ. Sci. Technol., 40, 5312-5318, 2006.

Wu, Y., Streets, D. G., Wang, S. X., and Hao, J. M.: Uncertainties in estimating mercury emissions from coal-fired power plants in China, Atmos. Chem. Phys., 10, 2937-2946, doi:10.5194/acp10-2937-2010, 2010. 